\title{
Antifungal effect of carbonate and bicarbonate salts against Botrytis cinerea, the casual agent of grey mould of kiwifruit
}

\author{
Muharrem TÜRKKAN ${ }^{1}$, Muharrem ÖZCAN², İsmail ERPER ${ }^{3}$
}

${ }^{1}$ Ordu University, Agriculture Faculty, Plant Protection Department, ORDU

${ }^{2}$ Ondokuz Mayıs University, Agriculture Faculty, Horticulture Department, SAMSUN

${ }^{3}$ Ondokuz Mayıs University, Agriculture Faculty, Plant Protection Department, SAMSUN

Alınış tarihi: 17 Mart 2017, Kabul tarihi: 27 Eylül 2017

Sorumlu yazar: Muharrem TÜRKKAN, e-posta: muharremturkkan@odu.edu.tr

\begin{abstract}
Control of grey mould of kiwifruit caused by Botrytis cinerea has been accomplished by postharvest application of synthetic fungicides. However, the development of resistant fungal strains and increasing public concern over food safety and the environment are driving a search for alternative disease control strategies. In the present study, the inhibitory effect of carbonate and bicarbonate salts of ammonium, potassium and sodium against $B$. cinerea were investigated in both in vitro and in vivo experiments. Ammonium carbonate, ammonium bicarbonate, sodium carbonate, sodium bicarbonate, potassium carbonate and potassium bicarbonate completely inhibited the mycelial growth of $B$. cinerea at 10, 25, 25, 50, 50 and $75 \mathrm{mM}$, respectively. With the exceptions of few, carbonate and bicarbonate salts totaly halted spore germination at lower concentrations than that of the mycelial growth of fungus. Complete inhibitory activity of ammonium carbonate exhibited spore germination at $10 \mathrm{mM}$, whereas same concentration of sodium carbonate reduced spore germination of fungus by 98.75\%; however, the difference between this and the effects of first salt was not statistically significant $(\mathrm{P}<0.05)$. The lowest minimum inhibition concentration (MIC) and $\mathrm{EC}_{50}$ values were also recorded in ammonium carbonate treatment. In vivo, however, with the exception of $100 \mathrm{mM}$ ammonium carbonate, five other carbonate and bicarbonate salts significantly reduced the incidence of grey mould on kiwifruits (cv. Hayward). Moreover, potassium bicarbonate was detected to be the most effective salt for in vivo control of disease, and the
\end{abstract}

difference between the effects of the lowest and highest concentrations of the salt was not statistically significant $(\mathrm{P}<0.05)$. Results from this study may provide an important basis for further study on the uses of carbonate and bicarbonate salts in the control of grey mould in kiwifruit at wider semi-commercial conditions.

Anahtar kelimeler: Kiwifruit, Botrytis cinerea, carbonate and bicarbonate salts, alternative control

\section{Kivilerde kurşuni küfe neden olan Botrytis cinerea'ya karşı karbonat ve bikarbonat tuzlarının antifungal etkisi}

Öz

Botrytis cinerea tarafından neden olunan kurşuni küfün kontrolü sentetik fungisitlerin hasat sonrası uygulaması ile bașarılmaktadır. Ancak, dirençli fungal rrkların gelişimi, gıda güvenliği ve çevre konusundaki toplumun artan endişesi alternatif hastalık kontrol stratejileri için bir arayışa yol açmıştır. Mevcut çalışmada, amonyum, potasyum ve sodyumun karbonat ve bikarbonat tuzlarının $B$. cinerea'ya karșı engelleyici etkileri hem in vitro hem de in vivo denemelerle araștırılmıștır. Amonyum karbonat, amonyum bikarbonat, sodyum karbonat, sodyum bikarbonat, potasyum karbonat ve potasyum bikarbonatın sırası ile 10, 25, 25, 50, 50 and $75 \mathrm{mM}$ konsantrasyonları in vitro'da $B$. cinerea'nın miselyal gelişimini tamamen engellemiş̧tir. Birkaç istisna dişında, karbonat ve bikarbonat tuzları fungusun miselyal gelişmesinden daha düşük konsantrasyonlarda spor çimlenmesini tamamen engellemiştir. Amonyum karbonatın spor 
çimlenmesini tam engelleme aktivitesi $10 \mathrm{mM}$ 'da ortaya çıkmış, halbuki sodyum karbonatın aynı konsantrasyonu spor çimlenmesini \% 98.75’e kadar azaltmıştır. Ancak ilk ve ikinci tuz etkileri arasındaki farklılı istatistiksel olarak önemsiz bulunmuştur $(\mathrm{P}<0.05)$. En düşük minimum engelleme konsantrasyonu (MIC) ve $\mathrm{EC}_{50}$ değerleri de amonyum denemelerinde kaydedilmiştir. Ancak in vivo'da amonyum karbonatın $100 \mathrm{mM}$ konsantrasyonu hariç, diğer beş karbonat ve bikarbonat tuzu kivilerde kurşuni küfü önemli oranda azaltmıştır. Dahası potasyum bikarbonatın in vivo hastalık kontrolünde en etkili tuz olduğu belirlenmiștir ve bu tuzun en düşük ve en yüksek konsantrasyonlarının etkileri arasındaki farklılık istatiksel olarak önemli bulunmamıștır $(\mathrm{P}<0.05)$. Bu çalışmadan elde edilen sonuçlar, daha geniş yarı ticari koşullarda kivilerde kurşuni küf kontrolünde karbonat ve bikarbonat tuzlarının kullanımıyla ilgili daha ileri çalışmalar için önemli bir temel sağlayabilir.

Key words: Kivi, Botrytis cinerea, karbonat ve bikarbonat tuzları, alternatif control

\section{Introduction}

Kiwifruit [Actinidia deliciosa (A. Chev.) C. F. Liang \& A. R. Ferg.] has been recently introduced as a potential commercial crop in Turkey. According to FAO records in 2016, Turkey was the world's seventh largest kiwifruit producer with a total cultivation area of 24.108 da from which $41.640 \mathrm{t}$ of fruits are currently harvested (FAO 2016, TUIKK 2016). Kiwifruit production is negatively affected by pre and postharvest pathogens. After harvest, postharvest fungal diseases including Botrytis cinerea, Diaporthe actinidiae, Sclerotinia sclerotiorum, Botryosphaeria dothidea, Cadophora luteo-olivacea and Mucor piriformis can cause losses of kiwifruit (Brook 1986). Moreover, the losses can even reach $32 \%$ in certain countries, such as Korea (Koh et al. 2005). B. cinerea, which causing stem-end rot, is regarded as the most important because environmental conditions prevailing during storage facilities are favourable to its development and infection (Pennycook, 1985; Sommer, 1985; Koh et al. 2003). Disease agent may cause serious economic losses on a wide range of matured fruit through secretion of a number of endo-polygalacturonases (EPGa enzymes) involved in pathogenesis (ten Have et al. 1998). The main control measure against the disease by applying fungicides such as iprodione, fenhexamide, imazalil, folpet, or cyprodinil+fludioxonil (Delen, 2016). Traditional chemical fungicides have had measurable success, but $B$. cinerea has developed resistance to common fungicides used to control grey mold. For example, populations of $B$. cinerea resistance to benzimidazole (benomyl) and dicarboximide (iprodione) fungicides has been documented in the United States and Canada (Northover and Matteoni, 1986; Moorman and Lease, 1992). However, the negative effects of these chemicals on both the environmental and public health have led to their banning in many countries (Fan et al. 2008). The use of natural compounds, such as organic and inorganic salts either alone or in combination with other control methods, appears to represent one of the best alternatives to synthetic fungicides for grey mold disease (Soylu et al. 2010; Türkkan and Erper 2014). The main advantages of using salt compounds include their relatively low mammalian toxicity, a broad spectrum of modes of action and relatively low cost (Olivier et al. 1998). Bicarbonate and carbonate salts of ammonium, sodium and potassium have been shown to inhibit fungal pathogens of fruits, field crops, vegetables and ornamentals (DePasquale et al. 1990 a, b; Ziv and Zitter 1992; Punja and Gaye 1993; Aharoni et al. 1997; Palmer et al. 1997; Campanella et al. 2002; Palou et al. 2002; Arslan et al. 2009; Erper et al. 2011; Latifa et al. 2011). With the exception of potassium carbonate, the remaining other bicarbonate and carbonate salts are generally recognised as safe (GRAS) by the United States Food and Drug Administration (FDA) (Anonymous 2016).

The objective of the present study was to evaluate the efficacy of carbonate and bicarbonate salts of ammonium, potassium and sodium for the control of $B$. cinerea. Inhibitory effects of the salts on the mycelial growth and conidial germination of the fungus were evaluated by in vitro tests, then the effect of salts on kiwifruit against $B$. cinerea were determined in in vivo test.

\section{Material and Methods}

\section{Fungal isolate}

The isolate of $B$. cinerea used in the study was isolated from decayed postharvest fruit of kiwifruit in Samsun province in Black Sea Region of Turkey. The isolate was maintained on potato dextrose agar (PDA; BD Difco, Sparks, USA). PDA slants were stored at $4{ }^{\circ} \mathrm{C}$. 


\section{Fruit}

Kiwifruits (cv. Hayward) were obtained from commercial orchards in Samsun, Turkey. The fruit had not received any pre-harvest fungicide treatment at least in the month before harvest, and were used immediately following harvest or after short storage at $+1{ }^{\circ} \mathrm{C}$.

\section{Chemicals}

Bicarbonate and carbonate salts of ammonium, potassium and sodium were purchased from Merck Chemicals (Merck, Darmstadt, Germany).

\section{Effect of salts on mycelial growth and spore germination}

The effect of bicarbonate and carbonate salts of ammonium, potassium and sodium on mycelial growth of $B$. cinerea were assayed according to Türkkan (2015) with a slight modification. 10, 25, 50,75 , or $100 \mathrm{mM}$ concentrations of the salts added to autoclaved and cooled PDA medium at $50^{\circ} \mathrm{C}$. For each salt, a $20 \mathrm{~mL}$ aliquot of ameliorated PDA medium was aseptically dispensed into 9-cm-dia. Petri plate, with an unamended PDA plate used as a control. A 5-mm-dia. mycelial disk cut from a 7-dayold fungal culture was placed in the center of each plate, which was then sealed with Parafilm and incubated at at $25^{\circ} \mathrm{C}$. Mycelial growth was measured daily at two perpendicular colony diameters until growth reached the edge of the Petri plates in the control. Mycelial growth values were converted into the inhibition percentage of mycelial growth inhibition (MGI) in relation to the controls using the formula, MGI $(\%)=[(\mathrm{dc}-\mathrm{dt}) / \mathrm{dc}] \times 100$, where $\mathrm{dc}$ and $\mathrm{dt}$ represent mycelial growth diameter in the control and amended Petri plates, respectively. Each treatment was replicated 4 times and was repeated twice.

To assess the effects of the six salts on $B$. cinerea spore germination, $20 \mu \mathrm{L}$ aliquots of conidial suspensions $\left(1 \times 10^{4}\right.$ conidia/mL) were plated on $1 \%$ agar flake (9 $\mathrm{mm}$ in diameter) mounted with different concentrations $(0,10,25,50,75$, or 100 $\mathrm{mM}$ ) of bicarbonate and carbonate salts of ammonium, potassium and sodium, and then incubated in petri plates at $25^{\circ} \mathrm{C}$, after $24 \mathrm{~h}$ of incubation, conidial germination rates were evaluated by counting of 100 conidia on per treatment replicate under an Olympus CX-31 compound microscope at 100 to $400 x$ magnification. The level of mortality was based on 100 spores and expressed as a percentage: \{[germinated spores (control) - germinated spores (salt solution)]/ germinated spores (control) $\} \times 100$ (Mecteau et. al. 2002).

\section{EC $_{50}$ and MIC values of salts}

The effective doses of salts that cause $50 \%$ inhibition $\left(\mathrm{EC}_{50}\right)$ of mycelial growth and spore germination were determined by probit analysis (IBM SPSS Statistics). The minimum inhibition concentration (MIC) that completely inhibited the mycelial growth/spore germination was determined was also determined in parallel experiments.

\section{Fruit inoculation}

Kiwifruits were punctured with a probe with a $3 \times 3$ $\mathrm{mm}$ tip that had been inoculated with $B$. cinerea spore suspension just before apply. For the treatment of each salt $(25 \mu \mathrm{L})$ at $100 \mathrm{mM}$ and 250 $\mathrm{mM}$ concentrations was applied to the wounds, followed by inoculation with of $B$. cinerea conidial suspension $\left(20 \mu \mathrm{L} ; 1 \times 10^{4}\right.$ conidia $\left./ \mathrm{mL}\right)$. A control treatment of distilled water $(25 \mu \mathrm{L})$ followed by inoculation with conidial suspension $(20 \mu \mathrm{L})$ of $B$. cinerea was performed. The kiwifruits were placed in plastic boxes $(20 \times 15 \mathrm{~cm})$. After incubation at $20 \pm$ $1^{\circ} \mathrm{C}$ and $85 \pm 5 \%$ R.H. for 7 days, image of the lesion area on kiwifruit was copied to a transparent paper. Images were then scanned into a digital format using a Mustek 1200 UB Plus desktop scanner (Mustek Systems, Inc., China), and the final versions of scanned images were saved as bmp 24-bit file. Lesion area was measured by using public domain software (Digimizer, Version 4.0.0.0 for MS Windows 2005-2011). The ratio of lesion area in the salts amended kiwifruit to that of control was determined as percentage inhibition. Treatment was replicated 8 times for each salt (Nunes et al. 2001).

\section{Statistical analysis}

The statistical analysis was performed using the statistical software SPSS (version 19, Property of SPSS, Inc.; IBM Company, Chicago, USA). Results were separately subjected to one-way analysis of variance (ANOVA), and significant differences between means were determined by using the Tukey-HSD test $(\mathrm{P}<0.05)$.

\section{Result and Discussion}

Ammonium carbonate completely inhibited the mycelial growth of $B$. cinerea at $10 \mathrm{mM}$, whereas five other carbonate and bicarbonate salts inhibited mycelial growth at rates from between 43.59 and $67.71 \%$ at same concentration $(\mathrm{P}<0.05)$ (Table 1$)$. Moreover, ammonium bicarbonate, potassium 
bicarbonate, potassium carbonate, sodium bicarbonate and sodium carbonate concentrations of $25,75,50,50$ and $25 \mathrm{mM}$, respectively, were required to completely inhibit mycelial growth of the fungus. However, ammonium bicarbonate and ammonium carbonate totaly inhibited spore germination of the fungus even at the lowest concentration tested. Sodium carbonate also reduced spore germination by $98.75 \%$, and the difference between this and the effects of the first group of salts was not statistically significant $(\mathrm{P}<0.05)$. In contrast, potassium and sodium bicarbonate affected slightly the spore germination of the fungus at $10 \mathrm{mM}$ and was no significant different from that of the control $(\mathrm{P}<0.05)$. Potassium carbonate, sodium bicarbonate and potassium bicarbonate concentrations of 25,50 and 50, respectively, were required to completely inhibit spore germination of the fungus. In line with the present study, previous studies have also shown carbonate and bicarbonate salts including ammonium, sodium and potassium to have inhibitory effects on the mycelial growth of different fungi (Palmer et al. 1997; Palou et al. 2001; Droby et al. 2003; Latifa et al. 2011 Youssef et al. 2012). Palmer et al. (1997) observed that ammonium carbonate and bicarbonate salts had a greater inhibitory effect on $B$. cinerea than other carbonate and bicarbonate salts, and ammonium bicarbonate also halted colony formation of the fungus at $20 \mathrm{mM}$ (fungitoxic), whereas potassium bicarbonate was unable to completely inhibit mycelial growth, even at the highest concentrations tested (150 mM = 1.5\%).
Similarly, Bombelli and Wright (2006) found that potassium bicarbonate reduced the mycelial growth of $B$. cinerea to some extent (65\%) at $0.5 \%$; and were required to complete inhibitory activity at $1 \%$ and higher concentrations. Droby et al. (2003) determined that sodium bicarbonate completely inhibited mycelial growth of $B$. cinerea and Penicillium expansum at 0.7 and $0.8 \%$, respectively. Moreover, some researhers showed that sodium carbonate and bicarbonate salts exhibited fungistatic rather fungicidal activity against many fungi, unlike ammonium carbonate and bicarbonate (Punja and Grogan, 1982; Depasquale and Montville, 1990b; Palou et al. 2001; Latifa et al. 2011). The inhibitory effect of bicarbonate salts on fungi was probably due to the reduction in fungal cell turgor pressure which resulted in collapse and shrinkage of hyphae and spores, and consequent inability of fungi to sporulate (Fallik et al. 1997). Palmer et al. (1997) also reported that the ammonium cation also contributed greatly to fungal growth inhibition, although the bicarbonate anion primarily affected fungal growth. Of bicarbonate and carbonate salts examined in the present study, ammonium carbonate was found to have the greatest toxicity against both mycelial growth and spore germination of $B$. cinerea, followed by ammonium bicarbonate and sodium carbonate (Table 2). According to their MIC and $\mathrm{EC}_{50}$ values, carbonate salts of ammonium, potassium and sodium were more toxic than bicarbonate salts of those. MIC values were consistent with $\mathrm{EC}_{50}$ values in the salts tested.

Table 1. Effect of carbonate and bicarbonate salts of ammonium, potassium and sodium on the mycelial growth and spore germination of Botrytis cinera

\begin{tabular}{|c|c|c|c|}
\hline \multirow{2}{*}{ Salts } & \multirow{2}{*}{$\begin{array}{c}\text { Concentration } \\
(\mathrm{mM})\end{array}$} & \multicolumn{2}{|c|}{ \% Inhibition } \\
\hline & & Mycelial growth & Spore germination \\
\hline \multirow{2}{*}{ Ammonium bicarbonate } & 10 & $67.71 \mathrm{~d}^{\mathrm{a}}$ & $100.00 \mathrm{a}$ \\
\hline & 25 & $100.00 \mathrm{a}$ & $100.00 \mathrm{a}$ \\
\hline Ammonium carbonate & 10 & $100.00 \mathrm{a}$ & $100.00 \mathrm{a}$ \\
\hline \multirow{4}{*}{ Potassium bicarbonate } & 10 & $43.59 \mathrm{~g}$ & $1.25 \mathrm{~d}$ \\
\hline & 25 & $73.94 \mathrm{~cd}$ & $76.50 \mathrm{~b}$ \\
\hline & 50 & $81.82 \mathrm{~b}$ & $100.00 \mathrm{a}$ \\
\hline & 75 & $100.00 \quad \mathrm{a}$ & $100.00 \quad \mathrm{a}$ \\
\hline \multirow{3}{*}{ Potassium carbonate } & 10 & $49.41 \mathrm{fg}$ & $30.75 \mathrm{c}$ \\
\hline & 25 & 88.32 b & $100.00 \mathrm{a}$ \\
\hline & 50 & $100.00 \quad \mathrm{a}$ & $100.00 \mathrm{a}$ \\
\hline \multirow{3}{*}{ Sodium bicarbonate } & 10 & 51.07 ef & $2.00 \mathrm{~d}$ \\
\hline & 25 & $74.37 \mathrm{c}$ & $78.00 \mathrm{~b}$ \\
\hline & 50 & $100.00 \mathrm{a}$ & $100.00 \mathrm{a}$ \\
\hline \multirow{2}{*}{ Sodium carbonate } & 10 & $57.09 \mathrm{e}$ & $98.75 \mathrm{a}$ \\
\hline & 25 & $100.00 \mathrm{a}$ & $100.00 \mathrm{a}$ \\
\hline Control & 0 & $0.00 \mathrm{~h}$ & $0.00 \mathrm{~d}$ \\
\hline
\end{tabular}

aMeans followed by the same letter are not significant different according to the Tukey's HSD $(\mathrm{P}<0.05)$. 
Table 2. $\mathrm{EC}_{50}$ and MIC values of bicarbonate and carbonate salts of ammonium, potassium and sodium tested against Botrytis cinerea

\begin{tabular}{lcccc}
\hline \multirow{2}{*}{ Salts } & \multicolumn{2}{c}{ Mycelial growth } & \multicolumn{2}{c}{ Spore germination } \\
\cline { 2 - 5 } & $\mathrm{EC}_{50^{\mathrm{a}}}$ & $\mathrm{MIC}^{\mathrm{b}}$ & $\mathrm{EC}_{50}$ & MIC \\
\hline Ammonium bicarbonate & $<10$ & 25 & $<10$ & 10 \\
Ammonium carbonate & $<10$ & 10 & $<10$ & 10 \\
Potassium bicarbonate & 12.77 & 75 & 19.99 & 50 \\
Potassium carbonate & 10.35 & 50 & 11.49 & 25 \\
Sodium bicarbonate & 10.98 & 50 & 19.44 & 50 \\
Sodium carbonate & $<10$ & 25 & $<10$ & 25 \\
\hline
\end{tabular}

aThe concentration that caused $50 \%$ reduction.

bMinimum inhibition concentration.

In vivo trials, unlike $100 \mathrm{mM}$ ammonium carbonate, five other carbonate and bicarbonate salts significantly reduced the incidence of grey mould symtomps on kiwifruits $(\mathrm{P}<0.05)$ (Table 3 and Figure 1). Among them, the most effective salt was determined to be potassium bicarbonate for in vivo control of the disease, followed by sodium carbonate, sodium bicarbonate, potassium carbonate, ammonium bicarbonate and ammonium carbonate, respectively. Generally, the differences between inhibitory effects of increased concentrations of the salts against the disease were statistically significant, whereas $100 \mathrm{mM} \mathrm{(1 \% )} \mathrm{and} 250 \mathrm{mM}$ (2.5\%) concentrations of potassium bicarbonate did not $(\mathrm{P}<0.05)$. These results are consistent with those of previous studies. Aharoni et al. (1997) showed that
$2 \%$ sodium bicarbonate has potential for controlling Rhizopus, Alternaria and Fusarium decay on different melons during prolonged storage and shelf-life, while maintaining fruit quality. Bombelli and Wright (2006) reported that potassium bicarbonate at concentrations below 2\%, demonstrated no protective effect against $B$. cinerea on tomato fruits, and moreover, applicationf of $2 \%$ potassium bicarbonate to be efficient in preventing an attack by the pathogen for two weeks. However, phytotoxic effects that caused depreciation of fruit quality have been reported by several reserchers in melon, pepper and tomatoes when applying potassium and sodium bicarbonate concentrations higher than $2 \%$ (Aharoni et al., 1997; Fallik et al., 1997; Bombelli and Wright 2006).

Table 3. Effect of carbonate and bicarbonate salts of ammonium, potassium and sodium on the development of grey mould caused by Botrytis cinerea on kiwifruit

\begin{tabular}{lcc}
\hline Salts & $\begin{array}{c}\text { Concentration } \\
(\mathrm{mM})\end{array}$ & Lesion area $\left(\mathrm{cm}^{2}\right)$ \\
\hline \multirow{2}{*}{ Ammonium bicarbonate } & 100 & $3.92 \mathrm{bcda}$ \\
& 250 & $3.97 \mathrm{bc}$ \\
\hline \multirow{2}{*}{ Ammonium carbonate } & 100 & $4.49 \mathrm{a}$ \\
\multirow{2}{*}{ Potassium bicarbonate } & 250 & $4.22 \mathrm{bc}$ \\
\hline \multirow{2}{*}{ Potassium carbonate } & 100 & $2.61 \mathrm{~g}$ \\
& 250 & $2.39 \mathrm{~g}$ \\
\hline \multirow{2}{*}{ Sodium bicarbonate } & 100 & $4.35 \mathrm{bc}$ \\
& 250 & $3.02 \mathrm{fg}$ \\
\hline \multirow{2}{*}{ Sodium carbonate } & 100 & $4.01 \mathrm{bc}$ \\
& 250 & $3.02 \mathrm{fg}$ \\
\hline Control (positive) & 100 & $3.56 \mathrm{def}$ \\
\hline
\end{tabular}

aMeans followed by the same letter are not significant different according to the Tukey's HSD $(\mathrm{P}<0.05)$. 

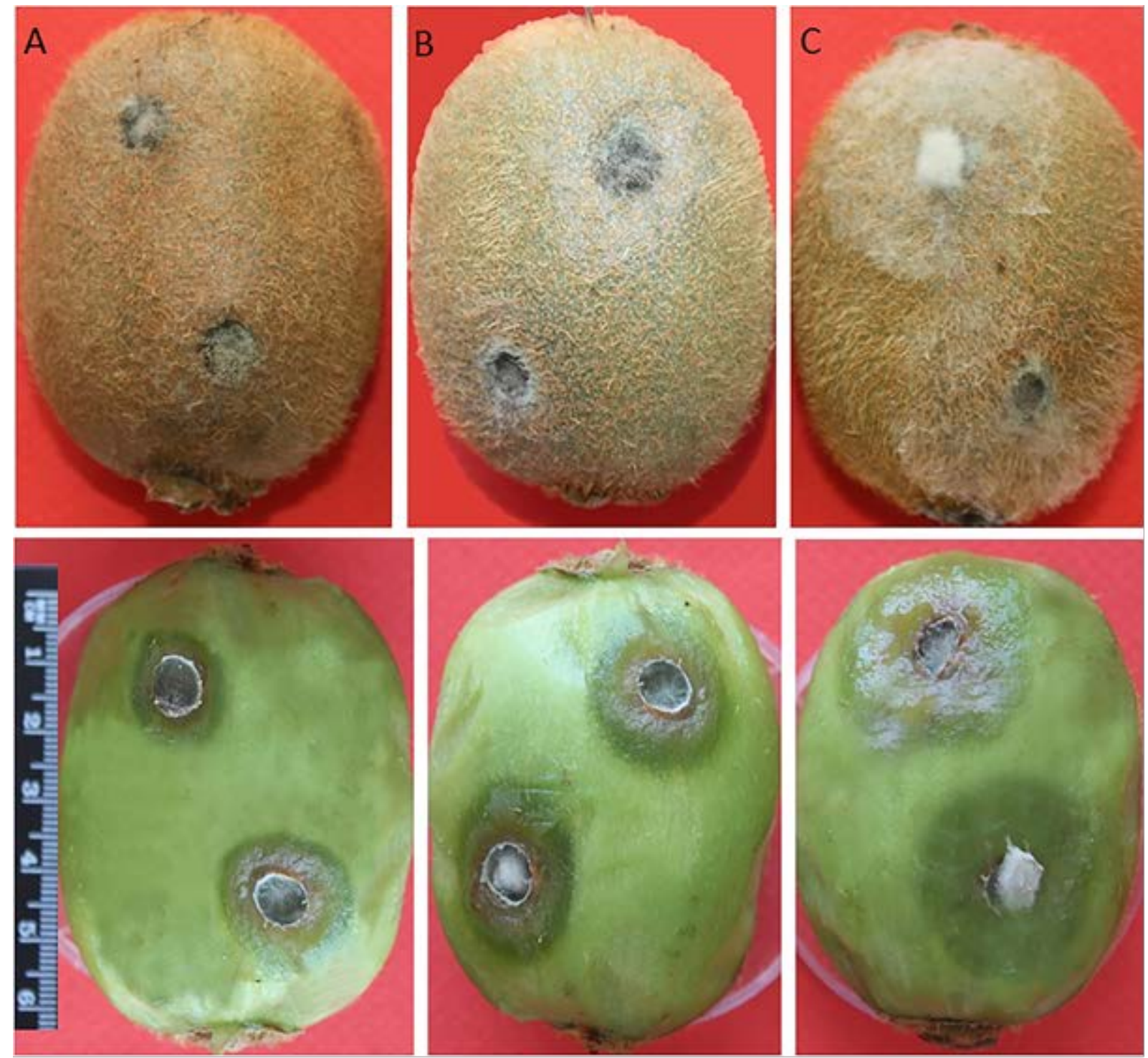

Figure 1. Activity of potassium bicarbonate (A) and ammonium carbonate (B) against grey mould of kiwifruit caused by Botrytis cinerea on double wounded kiwifruit as compared to inoculated control (C).

In conclusion, in the present study with carbonate and bicarbonates of ammonium, potassium and sodium, notable differences were determined between results of in vitro and in vivo trials. Wisniewski et al. (1998) found no correlation between the inhibitory effects in vitro and in vivo of different compounds used against $P$. digitatum and $B$. cinerea. For these reasons, our primary screenings were performed in vivo and we did not initially asses the toxicity of substances in vitro. Bicarbonate and carbonate salts have broad spectrum antimicrobial properties and are generally recognised as safe (GRAS) compounds which do not require expensive testing and validation by regulatory agencies. They are therefore very promising candidates for postharvest grey mould, especially in fresh commodities to which the application of synthetic fungicides is banned.

\section{Kaynaklar}

Aharoni, Y., Fallik, E, Copel, A., Gil, M., Grinberg, S., Klein. J. D. 1997. Sodium bicarbonate reduces postharvest decay development on melons. Postharvest Biol. Technol. 10:201-206.

Anonymous, 2016. U.S. Food and Drug Administration (FDA) http://www.fda.gov/Food/Ingredients PackagingLabeling/GRAS/ (verified May 06, 2016).

Arslan, U., Kadir, I., Vardar, C., and Karabulut, O. A. 2009. Evaluation of antifungal activity of food additives against soilborne phytopathogenic fungi. World 
Journal of Microbiology and Biotechnology 25: 537-543.

Bombelli E. C., Wright E. R. 2006. Tomato fruit quality conservation during post-harvest by application of potassium bicarbonate and its effect on Botrytis cinerea. Cien. Inv. Agr. 33(3): 167-172.

Brook, P. J. 1986. Diseases of kiwifruit. In 'Kiwifruit: science and management'. (Eds IJ Warrington, GC Weston). New Zealand, Ray Richards Publisher, 420-428.

Campanella, V., Ippolito, A., Nigro, F. 2002. Activity of calcium salts in controlling Phytophthora root rot of citrus. Crop Protection 21: 751-756.

Delen, N. 2016. Fungicides. Nobel Academic Publishing, Second Edt., Ankara, 552p.

DePasquale, D. A., El-Nabarawy, A., Rosen, J. D., Montville, T. J. 1990a. Ammonium bicarbonate inhibition of mycotoxigenic fungi and spoilage yeasts. Journal of Food Protection 53: 324-328.

Depasquale, D. A., Montville, T. J., 1990b. Mechanism by which ammonium bicarbonate and ammonium sulfate inhibit mycotoxigenic fungi. Appl. Environ. Microbial. 56:3711-3717.

Droby, S., Wisniewski, M. E., El Ghaouth, A., Wilson, C. 2003. Influence of food additives on the control of postharvest rots of apple and peach and efficacy of the yeast-based biocontrol product Aspire. Postharvest Biology and Technology 27: 127-135.

Erper, İ, Türkkan, M., Karaca, G.H., Kılıç, G., 2011. Evaluation of in vitro antifungal activity of potassium bicarbonate on Rhizoctonia solani AG 4 HG-I, Sclerotinia sclerotiorum and Trichoderma sp. African Journal of Biotechnology Vol. 10 (43): 8605-8612.

Fallik, E., S. Grinberg, O. Ziv, O., 1997. Potassium bicarbonate reduces postharvest decay development on bell pepper fruits. J. Hort. Sci. 72:35-41.

Fan C.M., Xıong G. R., Qi P., Ji G. H. He Y. Q. 2008. Potential biofumigation effects of Brassica oleracea var. caulorapa on growth of fungi. Journal of Phytopathology, 156:321-325.

FAO, 2016. Food and agriculture organization. The database of annual production. FAOSTAT. Statistical database. http:// faostat.fao.org. (verified December 10, 2016).

Koh Y. J., Jung J. S., Hur J. S., 2003. Current status of occurrence of major diseases on kiwifruits and their control in Korea. Acta Horticulturae 610: 437443.
Koh Y. J., Hur, J-S, Jung, J. S., 2005. Postharvest fruit rots of kiwifruit (Actinidia deliciosa) in Korea. New Zealand Journal of Crop and Horticultural Science 33: $303-310$

Latifa A., Idriss T., Hassan B., Amine S. M., El Hassane B. and Abdellah A. B. A., 2011. Effects of organic acids and salts on the development of Penicillium italicum: the causal agent of citrus blue mold. Plant Pathol Journal 10: 99-107.

Mecteau M. R., Arul J., Tweddell R. J. 2002. Effect of organic and inorganic salts on the growth and development of Fusarium sambucinum, a causal agent of potato dry rot. Mycol Res 106:688-696.

Moorman G. W., Lease, R. J. 1992. Benzimidazole- and dicarboximide-resistant Botrytis cinerea from Pennsylvania greenhouses. Plant Dis. 76:477-480.

Northover J., Matteoni J. A., 1986. Resistance of Botrytis cinerea to benomyl and iprodione in vineyards and greenhouses after exposure to the fungicides alone or mixed with captan. Plant Disease 70: 398-402.

Nunes C., Usall J., Teixido N, de Eribe X. O., Vinas I. 2001. Control of post-harvest decay of apples by preharvest and post-harvest application of ammonium molybdate. Pest Management Sci. 57: 1093-1099.

Olivier C., Halseth D.E., Mizubuti E.S.G., Loria R. 1998. Postharvest application of organic and inorganic salts for suppression of silver scurf on potato tubers. Plant Disease 82:213-217.

Palmer C. L., Horst R. K., Langhans R.W. 1997. Use of bicarbonates to inhibit in vitro colony growth of Botrytis cinerea. Plant Disease 81:1432-1438.

Palou, L., Smilanick, J. L., Usall, J., Viñas, I., 2001. Control of postharvest blue and green molds of oranges by hot water, sodium carbonate, and sodium bicarbonate. Plant Dis. 85: 371-376.

Palou, L., Usall, J., Smilanick, J.L., Aguilar, M-J., Vinas, I. 2002. Evaluation of food additives and low-toxicity compounds as alternative chemicals for the control of Penicillium digitatum and Penicillium italicum on citrus fruit. Pest Manag Sci 58: 459-466.

Pennycook S. R. 1985. Fungal fruit rots of Actinidia deliciosa (kiwifruit). New Zealand Journal of Experimental Agriculture 13: 289-299.

Punja, Z. K., Grogan, R. G., 1982. Effects of inorganic salts, carbonate-bicarbonate anions, ammonia, and the modifying influence of $\mathrm{pH}$ on sclerotial germination of Sclerotium rolfsii. Phytopathology 72:635-639.

Punja, Z. K., Gaye, M. M. 1993. Influence of postharvest handling practices and dip treatments on 
development of black root rot on fresh market carrots. Plant Dis 77:989-995.

Sommer, N. 1985. Role of controlled environments in suppression of postharvest diseases. Canadian Journal of Plant Pathology 7: 331.

Soylu, E. M., Kurt, Ş., Soylu, S. 2010. In vitro and in vivo antifungal activities of the essential oils of various plants against tomato grey mould disease agent Botrytis cinerea. International Journal of Food Microbiology 143:183-189.

Ten A., Mulder W., Visser J., van Kan J. A. 1998. The endopolygalacturonase gene Bcpg1 is required for full virulence of Botrytis cinerea. Mol Plant Microbe Interact 11 1009-1016.

TUIK, 2016. Agricultural Production Statistics of Turkish Statistical Institute. http://www.tuik.gov.tr/ bitkiselapp/bitkisel.zul (verified December 10, 2016).

Türkkan, M., Erper, İ., 2014. Multi Regression Analysis of The Effect of Potassium Bicarbonate on In Vitro The Mycelial Growth and Sclerotial Germination of
Botrytis cinerea. Akademik Ziraat Dergisi 3(2): 5360.

Türkkan, M., 2015. Evaluation of Inhibitory Effect of Organic and Inorganic Salts Against Ilyonectria liriodendri, The Causal Agent of Root Rot Disease of Kiwifruit. Journal of Phytopathology 163(7-8): 567577.

Wisniewski, M. E, Droby, S., El-Ghaouth, A. Wilson, C. L, 1998. The use of food additives to control postharvest decay and enhance biocontrol activity of yeast antagonist, in Proc Internat Congress Plant pathol, August 9-16, Edinburg, Scotlant, (Abstract 5.2.61).

Youssef, K., Ligorio, A., Sanzani, S. M., Nigro, F., Ippolito, A. 2012. Control of storage diseases of citrus by preand postharvest application of salts. Postharvest Biol Technol 72: 57-63.

Ziv, O., Zitter, T. A. 1992. Effects of bicarbonate and filmforming polymers on cucurbit foliar diseases. Plant Disease 76:513-517. 